\title{
Multivariate analysis and spatial distribution of suspended particulate metals of Abakaliki and Enugu in Southeastern Nigeria
}

\author{
Bright Chigozie Ichu' ${ }^{1}$ Alexander Iheanyichukwu Opara², Emmanuel Nnamdi Ejike², \\ Amarachi Udoka Nkwoada ${ }^{3^{*}}$ (1) Francis Chizoruo Ibe ${ }^{4}$ and Emmanuel Chuka Dioha ${ }^{2}$
}

\begin{abstract}
Background: The atmosphere is usually contaminated by heavy metals from different natural and anthropogenic sources. The levels of heavy metals in the atmosphere often become harmful and cause environmental pollution with serious health consequences to humans when their concentrations exceed certain threshold limits. The determination of the atmospherically suspended particulate matter in general and toxic trace metallic concentrations in particular, is, therefore, necessary for the evaluation of the sources and fate of atmospherically deposited suspended particulate matter. The assessment of the concentration levels of suspended particulate trace metals like $\mathrm{Zn}$ and Pb in the cities of Enugu and Abakaliki southeastern Nigeria was performed to assess the concentrations of atmospherically suspended metals in the area, their sources, and their pollution status.

Results: Results of the study showed that Zn concentration levels were not significant at all the sampling points, while the concentrations of Pb particulate matter which ranged from 0.11 to $0.91 \mu \mathrm{g} / \mathrm{m}^{3}$ exceeded the international revised EPA Pb standard of $0.15 \mu \mathrm{g} / \mathrm{m}^{3}$ but within the approved Federal Ministry of Environment (FMEnv) Nigeria, $24 \mathrm{~h}$ long duration of $1 \mu \mathrm{g} / \mathrm{m}^{3}$, and National Ambient Air Quality Standard (NAAQS) $1 \mathrm{~h}$ duration $\left(1 \mathrm{\mu g} / \mathrm{m}^{3}\right)$. The enrichment factor (EF) showed that $\mathrm{Pb}$ had a dominant crustal source, while $\mathrm{Zn}$ was determined to be of minor to moderate crust enrichment. The multivariate analysis carried out using principal component analysis (PCA) based on varimax rotation and Hierarchical Cluster Analysis (HCA) plotted in biplot and dendrogram diagrams revealed the levels of dependency and grouping, whereas Pearson's Correlation Coefficient $(P C)$ revealed a strong link between the two metallic pollutants

Conclusion: This study therefore which applied statistical and pollution assessment of atmospherically suspended particulate matter has revealed the importance of monitoring atmospherically suspended materials resulting from anthropogenic sources like mining, quarrying, construction, etc. Similarly, the use of statistical techniques like PCA, HCA, and Pearson's Correlation Coefficient to the study of ambient air quality has proved to be a useful tool in the assessment of atmospheric pollution. The findings of the present study therefore will be invaluable in the monitoring of particulate matter pollution of the atmosphere and their control measures, especially in mining districts.
\end{abstract}

Keywords: Heavy metal, Air pollution, Suspended particulate matter, Multivariate analysis

\footnotetext{
*Correspondence: amarachi.nkwoada@futo.edu.ng

${ }^{3}$ Department of Chemistry, Federal University of Technology Owerri,

P.M.B. 1526, Owerri, Imo, Nigeria

Full list of author information is available at the end of the article
}

\section{Background}

The widespread problem of air pollution ensuing from several developmental and anthropogenic activities associated with transportation, oil exploration, mining, and some other related fields is a major global challenge 
to a sustainable environment and is, therefore, a public health concern (Ibe et al. 2017; Ukaogo et al. 2020; Fagorite et al. 2021). Although several environmental measures are usually put in place at preferred locations in some major cities especially in developed countries to reduce and control the problem of air pollution problem, however many other emerging cities and old towns in developing countries are still facing these air pollution challenges (Ukaogo et al. 2020; Fagorite et al. 2021). The air pollutants can be transported to become part of biochemical cycles in the environment and may even enter the human body via the food chain as part of less harmful reactive products or harmless metabolites (Cimboláková et al. 2020; Shah 2021). They also may form part of the toxic environmental chemicals, that are persistent, toxic, with bioaccumulative potentials which have therefore necessitated the general public concerns to reduce their impact on human health and the environment (Ali et al. 2019; Briffa et al. 2020).

Therefore several researchers have worked on various processes, techniques, and methods for the removal of heavy metals in the environment using a combination of adsorbents, and noted that adsorbent mixtures have high removal efficiencies for heavy metals (ElShamy et al. 2017a, b, 2018; Migahed et al. 2017; Shehata et al. 2019). Other research works also revealed that they improve corrosion-resistant rate for mild steel after adding sodium haxa meta phosphate, especially in steel pipelines. The proposition, therefore, is that these research areas are evolving; and plant biomass, meso-porous adsorbents, and clays are some of the key adsorbents for heavy metal removal, metal recovery in flow systems for both batch and continuous processes (El-Shamy et al. 2017a, b, 2018; Migahed et al. 2017; Shehata et al. 2019). A similar challenge has been observed in the atmosphere as a result of atmospherically suspended and deposited particulate matter and metals, which are usually hazardous (Awan and Ahmed 2011). The Suspended Particulate Matter (SPM) present in the environment is well-known to cause harmful effects because the human tissue can absorb them via breathing. Additionally, when these suspended particulates containing some heavy metals in different forms are ingested or inhaled, they can result in very damaging health hazards (Obioh et al. 2005; Gray et al. 2015). Then again, climate and vegetation are also affected by SPM and this most often may lead to the occurrence of microbial pollution in the soil and the entire ecosystem (Sahu and Basti 2021). They can also cause photochemical smog, haze, and mists when the environment exceeds the natural capacity to dissipate, dilute or even absorb them, hence the need to study these atmospherically suspended pollutants (Chen et al. 2021).
The major sources of trace metallic elements in the atmosphere are often related to combustion, mining, and construction which result from particulate emission sources according to Mukherjee and Agrawal (2017). The main source of these suspended particulate matters and atmospherically suspended trace metals ( $\mathrm{Pb}, \mathrm{Zn}, \mathrm{Cd}$, etc.) are usually associated with anthropogenic sources rather than geogenic sources (Mukherjee and Agrawal 2017). This source has such components as traffic, transportation, mineral exploration, gas flaring, and power generation which have played dominant roles in air pollution studies (Maduna and Tomasic 2017).

Though the incidences of environmental pollution caused by heavy metals have been studied in different areas of the world (Abdul-Wahab 2006; Awan and Ahmed 2011; Adam 2013; Ikamaise et al. 2013; Seibokuro et al. 2018; Sintorini 2018; Rodriguez et al. 2019), there is however a paucity of data on the pollution and ecological risk assessment of atmospherically suspended trace metals. In Nigeria and especially within the study area, there is virtually no available literature on the challenges of SPM and heavy metals in the atmosphere. However, a lot of works have been done on ambient air quality study especially with respect to the gaseous criteria pollutants (Ibe et al. 2017). Similarly, the application of geostatistical techniques and pollution assessment models in evaluating the metallic concentrations, source, and fate of atmospherically suspended heavy metals in the atmosphere is quite new and has not been previously studied in the region. In addition, a thorough review of the studies revealed that pollutant concentration levels vary with the sources and distances to the pollutant source. Also, there is a general paradigm that pollutant concentration levels tend to escalate in areas witnessing emerging industrialization and urbanization owing to typical emission control problems in those cities. Hence, a regular comprehensive examination of particle geochemistry and ambient air quality change is pertinent (Douglas 2009; Basha et al. 2010; Maduna and Tomasic 2017).

Enugu and Abakaliki towns of southeastern Nigeria are located in the former east-central state and are associated with mining activities like quarrying. Minerals mined in the mining districts of Enugu and environs are largely associated with Coal while minerals mined from the several mining districts of Abakiliki and environs include lead $(\mathrm{Pb})$, Zinc $(\mathrm{Zn})$, salt, etc. Whereas Enugu is the Coal City and the former capital of defunct Southeastern Nigeria there is massive urbanization and associated activities in Abakaliki. Currently, both cities are capital cities of Enugu and Ebonyi states respectively with the attendant population increase, vehicular activities, industrial activities, etc. There have been several pollution sources resulting in high loadings of pollutants in the 
ambient air within these cities (Ngele and Onwu 2015; Awokola et al. 2020).

Because of the potentially detrimental effects of these toxic suspended heavy metals when in high concentrations in the atmosphere, the main objective of this work is, therefore, to assess the levels of $\mathrm{Zn}$ and $\mathrm{Pb}$ suspended particulate trace metals in the study area, their primary sources and their ecological and pollution risks. Both areas are associated with high levels of air pollution owing to several anthropogenic activities like mining. Despite the huge risk of atmospherically suspended metallic pollutants in this region, little or no studies have been done in this region to assess the metallic concentrations and their sources. Also, there is a scarcity of the application of statistical methods and pollution assessment techniques in the analysis of SPM in the region. Hence, various statistical techniques were used in evaluating the SPM/trace metals for spatial and multivariate analysis of the pollutants for a significant data reduction and interpretation of datasets.

\section{Methods}

In the present study, samples trapped within the study area on glass fiber filters by a high-volume sampler for quantification of $\mathrm{Zn}$ and $\mathrm{Pb}$ metals were analyzed using Atomic Absorption Spectroscopy via wet $\mathrm{HNO}_{3}$ acid digestion. Also. Arc GIS version 9.0 was used for mapping and geospatial analysis (See Additional file 1).

\section{Study area}

Abakaliki $\left(6^{\circ} 20^{\prime} \mathrm{N}\right.$ and $\left.8^{\circ} 06^{\prime} \mathrm{E}\right)$-lead mining and farming city, located in Ebonyi State and Enugu $\left(6^{\circ} 30^{\prime} \mathrm{N}\right.$ and $7^{\circ} 30^{\prime} \mathrm{E}$ ) - the city of Coal, located in Enugu State, both in the Southeast geopolitical zone of Nigeria. Both cities are currently the capital cities of Enugu and Ebonyi states. Abakaliki and Enugu have rich cultural heritage and thriving civilizations, and ethnic settlements in both states. As of the 2006 Nigeria census, Abakaliki had a population of 141,438 of which constitutes $48.45 \%$ males and $51.55 \%$ females, while Enugu had a population of 772, 664 in 2006 in which $49.2 \%$ were females and 52.25\% males (FRN 2009). Abakaliki has an average annual precipitation of $1250.7 \mathrm{~mm}$ per year while the Enugu region has an average annual rainfall of $2000 \mathrm{~mm}$ with May and October as the wettest months. The mean highest and lowest temperatures are $33-27^{\circ} \mathrm{C}$ and $29-26^{\circ} \mathrm{C}$ for Abakaliki and Enugu and Abakaliki respectively. Ebonyi state is a rich agricultural area and a leading producer of potatoes, yam, maize, cassava, rice, and beans within the region, with few commercial mines, and several solid mineral resources including zinc, lead metal, etc. On the contrary, the first European settlers in 1909 arrived in Enugu and made the first coal shipment by 1914 which largely fueled growth and development in the state. It is primarily a public sector-driven economy with few scattered industries food and beverage, brewery, cement, pharmaceutical and pottery, and machinery productions, and some mining activities (Ogbonna et al. 2014; Aloha et al. 2016).

\section{Sampling and analysis}

Ambient air monitoring was carried out at five different sites in the two locations namely ACM, ARS, AIN, AMN, and ARR for Abakaliki locations, and ECM, ERS, EIN, ECC, and ERR in Enugu locations and the references shown in Table 1. Note that from Table 1 the "A" and "E" stand for Abakaliki and Enugu, while the CM, RS, IN, $\mathrm{MN}$, and RR represents the commercial area, residential area, industrial area, mining area, and rural area respectively. Also, Fig. 1 is a representation of the sampling area within the study group, and locations adapted from the 2021 Google Earth Map and the location map adapted from the Nigerian Geological Survey Agency (NGSA) at 1:5000 and 1:10,000 scale respectively.

The determination of Zinc and Lead in the particulate matter (dust) was collected on glass fiber filter paper by Whatman within a sample area profile of $50 \times 60 \mathrm{~cm}^{2}$ ( $0.2 \mathrm{~mm}$ pore-size and about $98 \%$ collection efficiency) using a particulate monitor manufactured by Environmental Devices Corp., USA, operated at a constant flow rate $\left(1.3 \mathrm{~m}^{3} / \mathrm{min}\right)$ and programmed to collect $12 \mathrm{~h}$. samples. Using (U.S EPA 1990) model, the volume sampler was placed at a height of $4 \mathrm{~m}$ above ground level, while the recorded air volume passing through each filter was $1500 \mathrm{~m}^{3}$ and glass fiber filter papers were weighed before and after sampling. Hence, the mass of air passing through a sampler in $12 \mathrm{~h}$ is about $60-120 \mathrm{mg}$. It is important to note that the procedure for sampling was not followed on certain days due to excessive wind, heat, or equipment breakdown; however, it was rescheduled to different days and samples collected. A total of 20 samples were taken for each of the pollutants at the 10 different locations during August when the rains subsided for 1-2 weeks. An overview of the meteorological conditions is presented in Table 1.

After sampling, the filter paper was placed inside dark and air-tight plastic containers and taken to the laboratory for analysis of lead and zinc metals. Using the modified procedures described by Ercilla-Montserrat et al. (2018) and Basha et al. (2010), the glass filter papers were initially washed with deionized water, before drying in the oven at $105{ }^{\circ} \mathrm{C}$ to a constant weight. Furthermore, the filter papers were sliced into pieces and introduced into a plastic bottle containing $125 \mathrm{~mL}$ of $20 \%$ nitric acid solution placed inside a water bath shaker at $60{ }^{\circ} \mathrm{C}$ for $300 \mathrm{rpm}$. The obtained solution was poured into 
Table 1 Referenced location of air monitoring sampling area

\begin{tabular}{|c|c|c|c|c|}
\hline Name & Location & Status of site & Study code & Parameters \\
\hline \multicolumn{5}{|l|}{ Abakaliki } \\
\hline ACM 1,2,3,4 & New Market, Abakaliki & Commercial area with heavy traffic & ACM 1,2,3,4 & $\begin{array}{l}\text { Sampling period } \\
\text { July 2-3, } 2014\end{array}$ \\
\hline ARS $1,2,3,4$ & Okpa Ugwu & Residential area with medium traffic & ARS $1,2,3,4$ & $\begin{array}{l}\text { Wind speed } \\
0.5-2.5 \mathrm{~m} / \mathrm{s}\end{array}$ \\
\hline AIN $1,2,3,4$ & Abakaliki Rice Mill, Onuebonyi & Industrial area with heavy traffic & AIN $1,2,3,4$ & $\begin{array}{l}\text { Air Temperature } \\
34.5-40^{\circ} \mathrm{C}\end{array}$ \\
\hline AMN 1,2,3,4 & Onu Nwafor, Okposhi Umughara Quarry & Mining area with machinery and traffic & AMN 1,2,3,4 & $\begin{array}{l}\text { Relative humidity } \\
28-60 \%\end{array}$ \\
\hline ARR $1,2,3,4$ & Okposhi Umughara (control) & Rural area with low traffic and firewood burning & ARR $1,2,3,4$ & $\begin{array}{l}\text { Sampling Times } \\
6: 30 \mathrm{am} / \mathrm{pm}\end{array}$ \\
\hline \multicolumn{5}{|l|}{ Enugu } \\
\hline ECM 1,2,3,4 & Ogbete Main Market, Enugu & Commercial area with heavy traffic & ECM $1,2,3,4$ & $\begin{array}{l}\text { Sampling period } \\
\text { July } 2-3,2014\end{array}$ \\
\hline ERS $1,2,3,4$ & Abakpa Nike & Residential area with heavy traffic & ERS $1,2,3,4$ & \\
\hline EIN 1,2,3,4 & Emene Industrial Layout & Industrial area with medium traffic & EIN $1,2,3,4$ & $\begin{array}{l}\text { Wind speed } \\
0.7-2.8 \mathrm{~m} / \mathrm{s}\end{array}$ \\
\hline \multirow[t]{2}{*}{ ECC $1,2,3,4$} & Coal Camp & $\begin{array}{l}\text { Former mining area with industrial market heavy } \\
\text { machinery and traffic }\end{array}$ & ECC $1,2,3,4$ & $\begin{array}{l}\text { Air Temperature } \\
35-45 \text { oC }\end{array}$ \\
\hline & & & & $\begin{array}{l}\text { Relative humidity } \\
29-56 \%\end{array}$ \\
\hline ERR 1,2,3,4 (Control) & Edem Nike (control) & Rural area with low traffic and firewood burning & ERR $1,2,3,4$ & $\begin{array}{l}\text { Sampling Times } \\
6: 30 \mathrm{am} / \mathrm{pm}\end{array}$ \\
\hline
\end{tabular}

A Abakaliki, CC coal camp, CM commercial area, E Enugu, IN industrial area, $M N$ mining area, $R S$ residential area, $R R$ rural/reference area

a 250-mL borosilicate glass beaker and the bottle was rinsed 3 times with the deionized water.

The borosilicate beaker was then placed over a heated flame at $150{ }^{\circ} \mathrm{C}$ temperature to evaporate the nitric acid solution to $20 \mathrm{~mL}$. Furthermore, another $20 \mathrm{~mL}$ of analytical grade nitric acid was added to the beaker and boiling continued till a $10 \mathrm{~mL}$ volume was left. The aliquot was now filtered and filtrate stored in a $100 \mathrm{~mL}$ amber bottle in the dark until further analysis was conducted (Basha et al. 2007). The blank values were calculated by analyzing unused filter papers via the procedure described above. The samples were analyzed using (AAS) Atomic Absorption Spectroscopy (Buck Model 210 VGP) equipped with a digital readout system (U.S EPA 1999). The flow rates of air and acetylene from the storage cylinder were adjusted and analysis was performed accordingly. The concentrations of $\mathrm{Pb}$ and $\mathrm{Zn}$ in the samples were calculated by comparison with the standard curves of the respective metals. The detection limits of the chemical analysis for $\mathrm{Pb}$ and $\mathrm{Zn}$ were 0.085 and $0.052 \mathrm{mg} / \mathrm{L}$ respectively. Moreover, for each measurement at a particular site within a location, the mean was taken after sampling three times, and the calculated difference between the three determinants was less than $4.5 \%$. The calculated recovery efficiency for AAS was $94-97 \%$ of a known amount of the metal spiked unto clean filter papers before extraction and recovery. Specific hollow cathode lamps were used for each metal at their respective wavelengths (Gharaibeh et al. 2010).

\section{Results}

Table 1 shows the referenced location of the air monitoring sampling area. The particulate heavy metal concentrations in Abakaliki and a reference station ARR during August break are summarized in Table 2. Also, the particulate heavy metals concentrations in Enugu and a reference station ERR during August break are shown in Table 3. While the Pearsons Correlation Table is captured in Table 4, the mean of the three readings for each sampling site, median, and standard deviation as shown in the Tables. The spatial distribution of $\mathrm{Pb}$ within Abakaliki and Enugu is shown in Figs. 2 and 3 while the distribution of $\mathrm{Zn}$ metal in the sampling points is depicted in Fig. 4. The statistical biplot showing principal components and data subsets is shown in Fig. 5. Also, Fig. 6 represents the plot of the concentrations of $\mathrm{Pb}$ and $\mathrm{Zn}$ at Abakaliki and Enugu sampling sites respectively. Lastly, again the dendrogram showing the concentrations at the different sampling sites is shown in Fig. 7.

\section{Discussion}

Heavy metal concentrations

The numerical summary of metal concentration data obtained from ten monitoring sites including the 


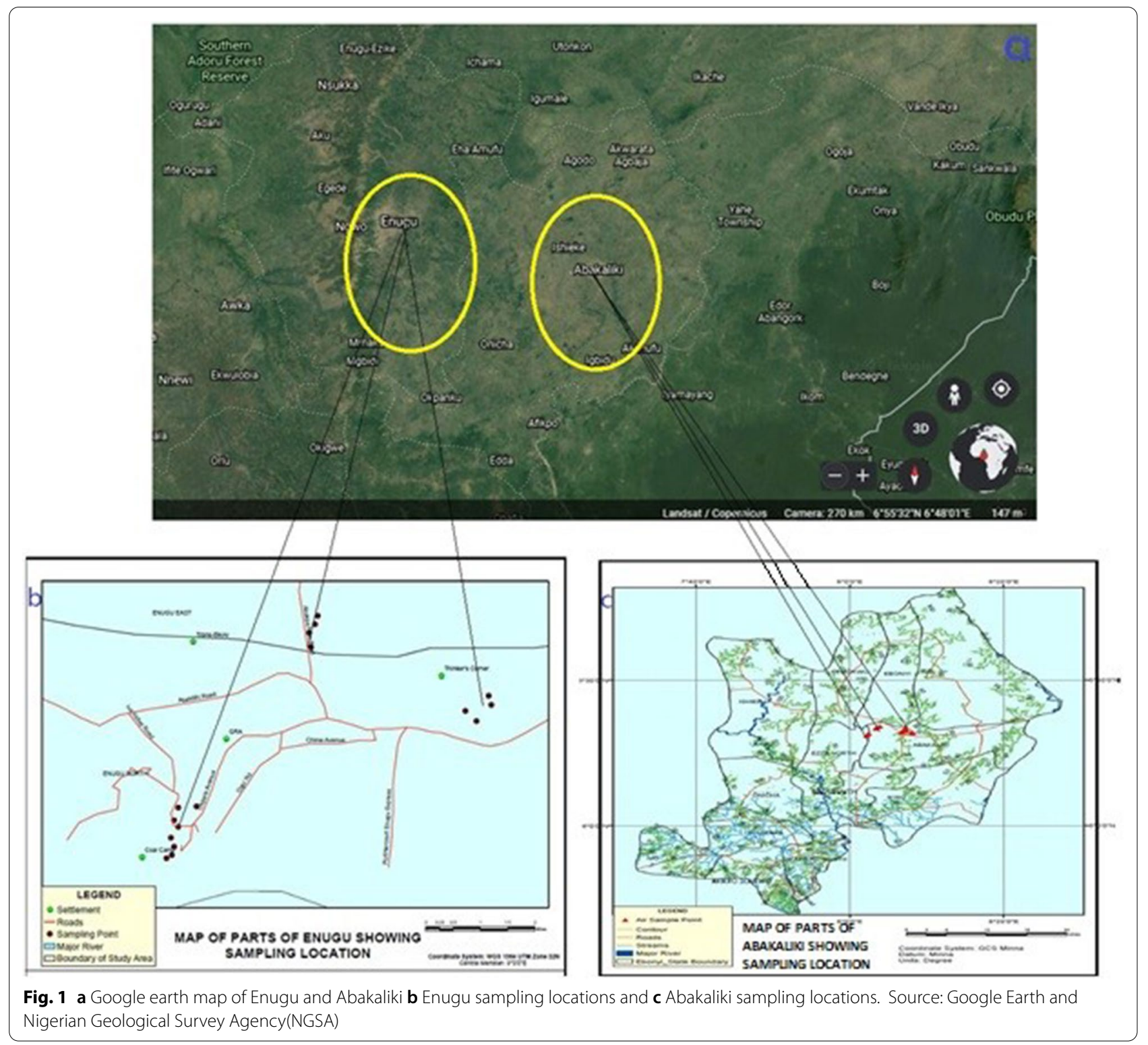

reference sites during the August break study period is presented in Tables 2 and 3. The mean metal concentrations $(\mathrm{Zn})$ remained at $0.030 \mu \mathrm{g} / \mathrm{m}^{3}$ at the reference sites ARR during the August break but were determined to be below the detection limit at the reference site ERR during the same period (Table 2) exhibiting no significant spatial variation. The mean concentration of $\mathrm{Pb}$ metal was $0.21 \mu \mathrm{g} / \mathrm{m}^{3}$ and $0.18 \mu \mathrm{g} / \mathrm{m}^{3}$ in ARR and ERR respectively, and therefore do not differ significantly.

The highest levels of $\mathrm{Pb}$ and $\mathrm{Zn}$ are found to be $0.91 \mu \mathrm{g} /$ $\mathrm{m}^{3}(\mathrm{AMN})$ and $0.050 \mu \mathrm{g} / \mathrm{m}^{3}(\mathrm{ECM})$ respectively. The highest $\mathrm{Pb}$ level at ARR and ERR is close to the approved FMEnv $24 \mathrm{~h}$. long duration of $1 \mu \mathrm{g} / \mathrm{m}^{3}$, NAAQS for $1 \mathrm{~h}$. duration $\left(1 \mathrm{ug} / \mathrm{m}^{3}\right)$, and $1.4 \mu \mathrm{g} / \mathrm{m}^{3}$ of (NESREA) National environmental standards and regulation agency, but it is a higher value when compared to the revised EPA lead standard of $0.15 \mu \mathrm{g} / \mathrm{m}^{3}$ as shown in Fig. 1 (Obioh et al. 2005; Aloha et al. 2016; Frank et al. 2019).

This toxic level of $\mathrm{Pb}$ puts the vulnerable human populace, especially children and the terrestrial ecosystem at risk. Research has shown that $\mathrm{Pb}$ exposures negatively affect the oxygen-carrying capacity of the blood and also result in decreased growth and reproduction among plants and animals in the ecosystems (Frank et al. 2019; Benibo et al. 2020; Ghosh et al. 2021). The sources of Pb within that area are mainly from lead-zinc mining and the heavyduty trucks that transport goods and raw materials from one town to the other. The heavy metals in SPM values for 
Table 2 Particulate heavy metals concentrations in Abakaliki and a reference station ARR during August break

\begin{tabular}{llllll}
\hline & ACM & ARS & AIN & AMN & ARR \\
\hline $\mathrm{Zn}\left(\mu \mathrm{g} / \mathrm{m}^{3}\right)$ & 0.040 & 0.040 & 0.040 & 0.040 & 0.030 \\
$\mathrm{Zn}\left(\mu \mathrm{g} / \mathrm{m}^{3}\right)$ & 0.040 & 0.040 & 0.040 & 0.040 & 0.030 \\
$\mathrm{Zn}\left(\mu \mathrm{g} / \mathrm{m}^{3}\right)$ & 0.040 & 0.030 & 0.030 & 0.030 & 0.030 \\
$\mathrm{Zn}\left(\mu \mathrm{g} / \mathrm{m}^{3}\right)$ & 0.040 & 0.030 & 0.020 & 0.030 & 0.030 \\
Mean & 0.040 & 0.035 & 0.033 & 0.035 & 0.030 \\
Median & 0.040 & 0.035 & 0.035 & 0.035 & 0.030 \\
$\mathrm{SD}$ & 0.000 & 0.005 & 0.009 & 0.005 & 0.000 \\
$\mathrm{~Pb}\left(\mu \mathrm{g} / \mathrm{m}^{3}\right)$ & 0.42 & 0.09 & 0.57 & 0.67 & 0.26 \\
$\mathrm{~Pb}\left(\mu \mathrm{g} / \mathrm{m}^{3}\right)$ & 0.40 & 0.09 & 0.26 & 0.80 & 0.28 \\
$\mathrm{~Pb}\left(\mu \mathrm{g} / \mathrm{m}^{3}\right)$ & 0.35 & 0.06 & 0.32 & 0.70 & 0.16 \\
$\mathrm{~Pb}\left(\mu \mathrm{g} / \mathrm{m}^{3}\right)$ & 0.46 & 0.07 & 0.09 & 0.91 & 0.14 \\
Mean & 0.41 & 0.08 & 0.31 & 0.77 & 0.21 \\
Median & 0.41 & 0.08 & 0.29 & 0.75 & 0.21 \\
$\mathrm{SD}$ & 0.05 & 0.02 & 0.20 & 0.11 & 0.07 \\
\hline
\end{tabular}

Table 3 Particulate heavy metals concentrations in Enugu and a reference station ERR during August break

\begin{tabular}{lccccc}
\hline & ECM & ERS & EIN & EMN & ERR \\
\hline $\mathrm{Zn}\left(\mu \mathrm{g} / \mathrm{m}^{3}\right)$ & 0.040 & 0.002 & 0.040 & 0.040 & $\mathrm{ND}$ \\
$\mathrm{Zn}\left(\mu \mathrm{g} / \mathrm{m}^{3}\right)$ & 0.050 & 0.005 & 0.003 & 0.003 & $\mathrm{ND}$ \\
$\mathrm{Zn}\left(\mu \mathrm{g} / \mathrm{m}^{3}\right)$ & 0.040 & $\mathrm{ND}$ & 0.035 & 0.035 & $\mathrm{ND}$ \\
$\mathrm{Zn}\left(\mu \mathrm{g} / \mathrm{m}^{3}\right)$ & 0.040 & 0.003 & 0.023 & 0.023 & $\mathrm{ND}$ \\
Mean & 0.043 & 0.003 & 0.025 & 0.025 & 0.00 \\
Median & 0.040 & 0.003 & 0.030 & 0.030 & 0.00 \\
$\mathrm{SD}$ & 0.005 & 0.002 & 0.016 & 0.016 & 0.00 \\
$\mathrm{~Pb}\left(\mu \mathrm{g} / \mathrm{m}^{3}\right)$ & 0.590 & 0.110 & 0.300 & 0.610 & 0.180 \\
$\mathrm{~Pb}\left(\mu \mathrm{g} / \mathrm{m}^{3}\right)$ & 0.650 & 0.090 & 0.260 & 0.650 & 0.170 \\
$\mathrm{~Pb}\left(\mu \mathrm{g} / \mathrm{m}^{3}\right)$ & 0.650 & 0.130 & 0.290 & 0.590 & 0.190 \\
$\mathrm{~Pb}\left(\mu \mathrm{g} / \mathrm{m}^{3}\right)$ & 0.640 & 0.130 & 0.270 & 0.590 & 0.200 \\
Mean & 0.632 & 0.115 & 0.280 & 0.610 & 0.185 \\
Median & 0.645 & 0.120 & 0.280 & 0.600 & 0.185 \\
$\mathrm{SD}$ & 0.028 & 0.019 & 0.018 & 0.028 & 0.013 \\
\hline
\end{tabular}

Table 4 Pearson's correlations between the suspended metal particulate matter

\begin{tabular}{lllll}
\hline & $\begin{array}{l}\text { Abakaliki } \\
\mathbf{Z n} / \mathbf{P b}\end{array}$ & $\begin{array}{l}\text { Enugu Zn/ } \\
\mathbf{P b}\end{array}$ & $\begin{array}{l}\text { Abakaliki/ } \\
\text { Enugu } \mathbf{Z n} / \\
\mathbf{Z n}\end{array}$ & $\begin{array}{l}\text { Enugu/ } \\
\mathbf{A b a k a l i k i} \\
\mathbf{P b} / \mathbf{P b}\end{array}$ \\
\hline Coefficient $(r)$ & 0.277 & 0.729 & 0.237 & 0.787 \\
$p$ value & 0.23 & $2.6 \mathrm{E}^{-04}$ & 0.313 & $3.7 \mathrm{E}^{-05}$ \\
$N$ & 20 & 20 & 20 & 20 \\
T statistics & 1.22 & 4.52 & 1.038 & 5.42 \\
DF & 18 & 18 & 18 & 18 \\
\hline
\end{tabular}

the measuring period ranged from 0.023 to $0.040 \mu \mathrm{g} / \mathrm{m}^{3}$ for $\mathrm{Zn}$ and 0.11 to $0.91 \mu \mathrm{g} / \mathrm{m}^{3}$ for $\mathrm{Pb}$, which were about many times higher than EPA reference values but a little lower than NAAQS and NESREA recommendations as depicted in Fig. 2.

Zinc metal is not listed as an occupational hazard neither is it carcinogenic; hence there is no established national ambient air quality standard for zinc except ingestion of zinc metal fumes for long durations. Also, the graph in Fig. 4 shows that zinc concentration is fairly constant and unaffected by relative humidity and wind speed in Enugu as similarly observed in Abakaliki. The mean concentrations of the metals derived from the values of each site are shown in Tables 2 and 3. In comparison, the reference sites ERR and ARR had lower mean concentrations for $\mathrm{Pb}$ at all sites $\left(0.21 \mu \mathrm{g} / \mathrm{m}^{3}\right)$. The mean concentration of $\mathrm{Zn}$ particulate matter was $0.030 \mu \mathrm{g} / \mathrm{m}^{3}$ at both reference sites (ARR and ERR) as seen in Fig. 4.

The mean concentration of $\mathrm{Pb}$ was found to be over two orders of magnitude than the EPA standard. Thus, in this study, the particulate metal concentration levels can be listed in the order of ranking as follows: $\mathrm{Zn}$ at Abakaliki $(A R R<A I N<A C M<A R S<A M N)$ and $\mathrm{Zn}$ at Enugu $(E R R<E R S<E I N<E M N<E C M) ; \quad \mathrm{Pb}$ at Abakaliki $(A R S<A R R<A I N<A C M<A M N)$ and $\mathrm{Pb}$ at Enugu $(E R S<E R R<E I N<E R S<E C M)$. Hence the magnitude of metal order can be divided into values $\leq 0.025 \leq 0.05 \mu \mathrm{g} /$ $\mathrm{m}^{3}$ for $\mathrm{Zn}$ and $\leq 0.05 \leq 0.1 \mu \mathrm{g} / \mathrm{m}^{3}$ for $\mathrm{Pb}$. About $50 \%$ of zinc concentration levels were lower than $0.025 \mu \mathrm{g} / \mathrm{m}^{3}$ while the remaining $50 \%$ were less than $0.05 \mu \mathrm{g} / \mathrm{m}^{3}$. The Pb grouping also shows that all sites exceeded $0.05 \mu \mathrm{g} / \mathrm{m}^{3}$ concentration levels. Thus, the relative arrangement shows no specific ordering for the metals but the dominance of $\mathrm{Pb}$ within the study sites. This result shows that $\mathrm{Pb}$ is the highest contributor of particulate matter load in the environment within the measured locations (Offor et al. 2016; Aloha et al. 2017; Ojekunle et al. 2018; Ichu et al. 2021).

\section{Pearson's correlation}

The Pearson's correlation (PC) is generally used to describe the proportion of the total variance in the obtained data and is explained by a linear model of the variables under consideration. The Pearson's correlation ranges from -1 to 1 , and higher absolute values indicate better dependency among the variables. The formula for Pearson's correlation between two random variables $x$ and $y$ is given below in Eq. 1 as:

$$
p_{x y}=\frac{\sigma_{x y}^{2}}{\sqrt{\sigma_{x}^{2} \sigma_{y}^{2}}}
$$

where $\sigma_{x}$ is known as the standard deviation of the variable $x, \sigma_{x}^{2}$ is known as the variance of $x, \sigma_{y}$ is known as 

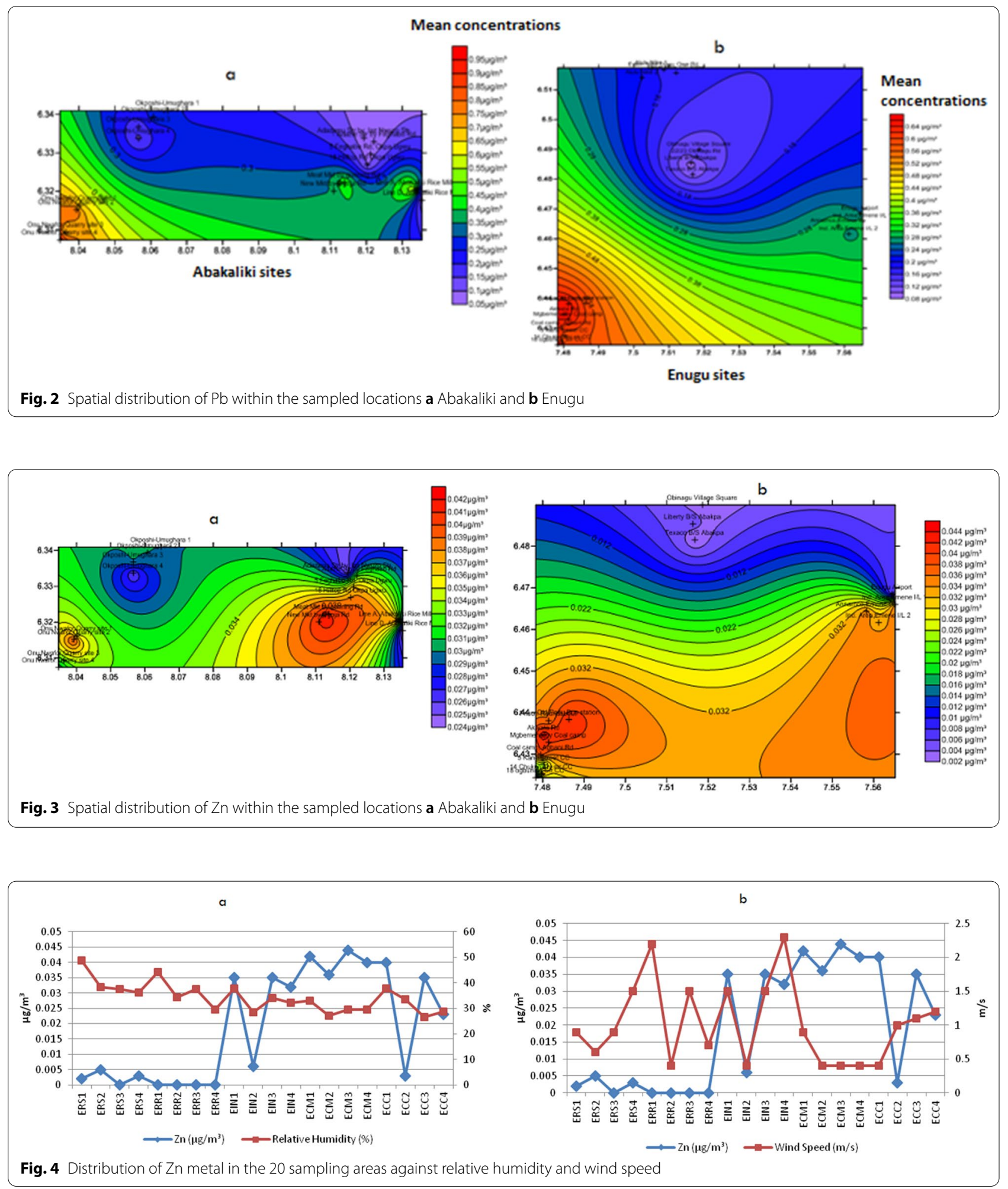

the standard deviation of the variable $y, \sigma^{2} y$ is known as the variance of $y$ and $\sigma_{x y}^{2}$ is known as the covariance of the variables of $x$ and $y$.
When two variables are found to be independent, Pearson's correlation coefficient will be 0 but the inverse is sometimes not always true because there are instances 

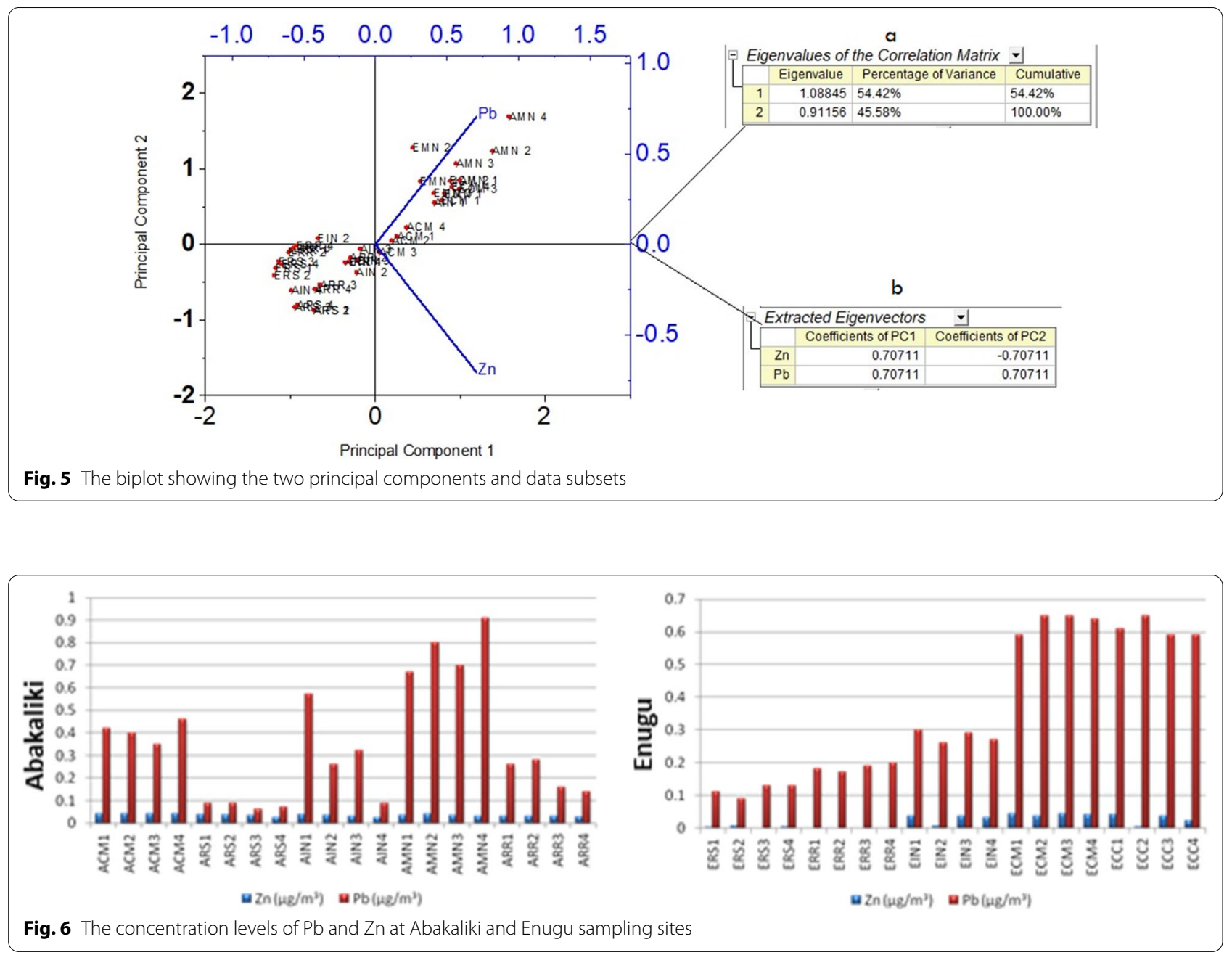

that have dependent variables and Pearson's correlation is unable to detect the dependency. Although it can exist, because Pearson's correlation recognizes the linear correlations between variables that are jointly, and normally distributed. However, two variables can be correlated but unable to follow linear correlation and Pearson's correlation failing to detect the dependency. One very useful factor in Pearson's correlation is the measurement of dependency is the $p$ value. It provides reliable information about the probability that a given dataset will be contrary to the hypothesis, in other words, the determined Pearson's correlation is not significant despite the value of $P_{x y}^{2}$. Thus, it is generally accepted that a $p$ value $\leq$ of 0.05 shows a significant correlation and a $p$ value $>0.05$ is not a significant correlation. Also, the coefficient of determination ', will give the percentage of PC between two variables. For instance, a $P_{x y}$ value of 0.5 and $P_{x y}^{2}$ value of 0.25 means that $25 \%$ of $y$ values are explained by values of $x$ (Bermudez-Edo et al. 2018; Hůnová 2020).
The results from Pearson's correlation data are presented in Table 4 above. The $p$ value is greater than 0.05 at Abakaliki and Abakaliki/Enugu ( $\mathrm{Zn} / \mathrm{Zn})$ which means that the correlation is not significant, hence the data is inconsistent with the hypothesis. But at all the sites in Enugu and Enugu/Abakaliki $(\mathrm{Pb} / \mathrm{Pb})$, the $p$ value was less than 0.05 which revealed that it is significant showing that the data is consistent with the hypothesis. The Pearson's correlation ( $r$ ) values of Abakaliki and Abakaliki/ Enugu also reflect a statistical negative correlation values and indicate that the levels of particulate heavy metals in Abakaliki differ from each other and are reasonable to study each as an independent variable. They also indicate a weak link for air pollutants moving from Abakaliki to Enugu. However, at Enugu and Enugu/Abakaliki sites it appears to contribute significantly (positive correlation) to the recorded concentrations. This also confirms that a strong link exists between the two pollutants at Enugu and the potential movement of pollutants from Enugu to 


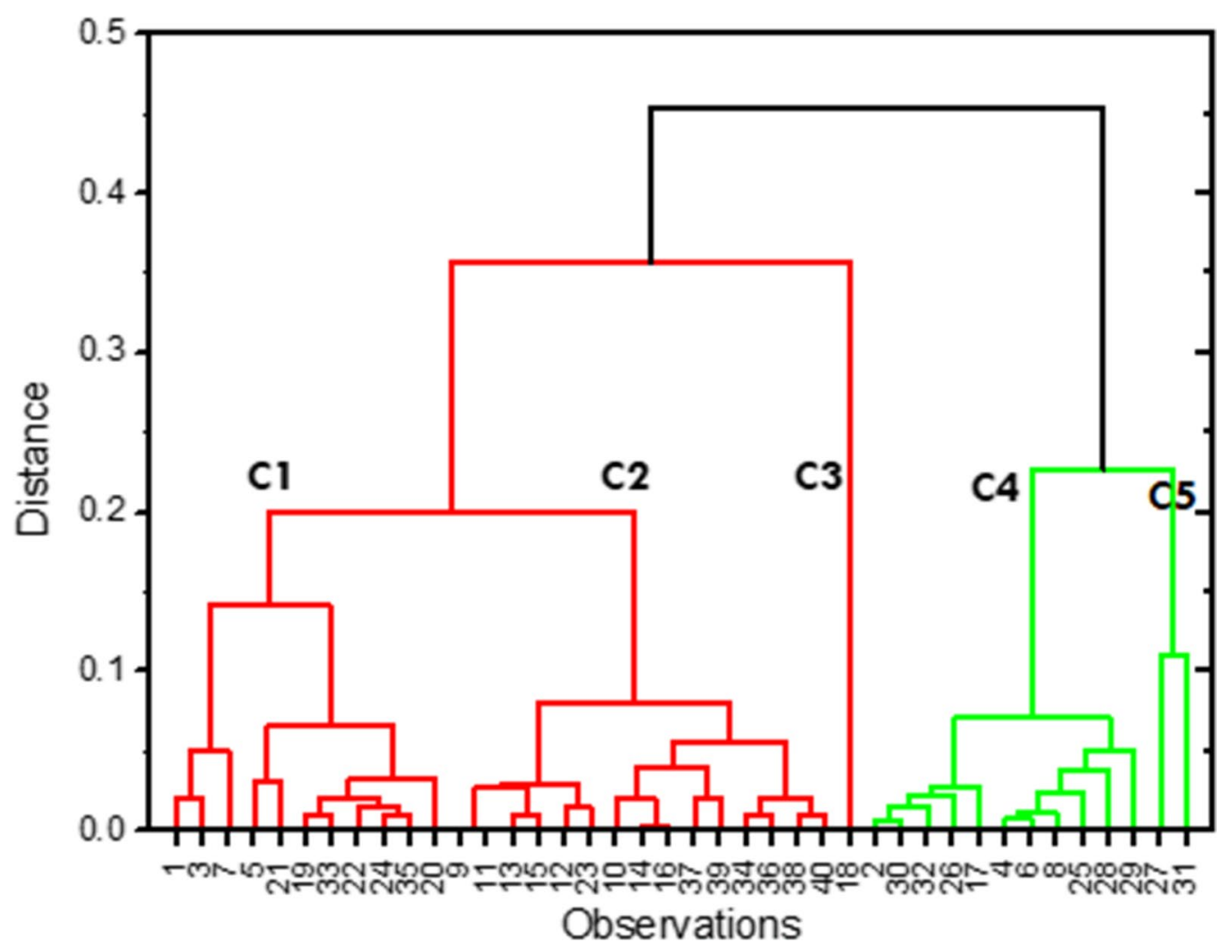

Fig. 7 Dendrogram of the concentration at the different sampling sites

Abakaliki. Hence, selecting a single variable that incorporates two or more particulate matter is justifiable.

\section{Principal component analysis (PCA)}

The Principal Component Analysis (PCA) is known to be a powerful tool commonly used to reduce the dimension of data. The identified principal components are typically expected to account for most of the variability of the datasets acquired from the different samples. Hence, the PCA uses the identified principal component to differentiate samples or subsets of samples that are seen to be responsible for the variations between the different groups. Moreover, the contribution from each data set can be visualized in the scatter plot of any two principal components to reveal the relative variation of the unrelated data sets (Yu et al. 2016). In this study, PCA was conducted by dividing the datasets into two subsets one for $\mathrm{Zn}$ and the other for Pb. As can be seen in Fig. 5, it depicted the biplot of two principal components of datasets. Using the varimax rotation criteria, new variable vari-factors (VFs) were formed and reduced to PCs after rotating the obtained PCs (Al-Anzi et al. 2016).

The Eigenvalues of the correlation matrix provided information on how many principal components should be considered because it is the principal component that accounts for most of the variance in the observed variable. Hence in the first obtained Eigenvalue as shown in Fig. 3 only $54.42 \%$ of data is covered while the second Eigenvalue covered the remaining $45.58 \%$ of data. A view of the screen plot shows how many principal components that are to be considered. It shows a visual indication of only 2 principal components to be considered which were adopted in the plot (Simeonov et al. 2004). From the extracted Eigenvalues, the coefficient principal component 1 is mainly the presence of $\mathrm{Zn}$ and $\mathrm{Pb}$ particulate metals while the coefficient of principal component 2 was mainly $\mathrm{Pb}$ particulate matter. The biplot displays both the loadings and the scores for the two selected components. The scatter plots show the different sample locations within Enugu and Abakaliki. Hence sampling site $A C M 3$ relies on $\mathrm{Zn}$ as the principal component which indicates that the primary pollutant at $A C M 3$ is $\mathrm{Zn}$ particulate matter while, (ACM 1-2, ACM 4, AMN 2-4, $E M N$ 2, EMN 4) are clustered around the $\mathrm{Pb}$ particulate matter which indicated that the primary source of those sampling sites is the Lead $(\mathrm{Pb})$ particulate matter. But for locations like (AIN 2-4, ARS 2-4, EIN 2, ERS 1-4, ERR 1-4, ERS 2, and ARR 2) their primary pollutant source cannot be established from the PCA. These observations from the data correlate with the simple plot shown 
below in Fig. 6 where the $\mathrm{Zn}$ particulate matter at ACM 1-4 was not statistically indicative and identified to be the primary pollutant (principal component 1 ) at ACM, while the $\mathrm{Pb}$ particulate matter at ACM 1-4 and ECM 1-4 were significantly obvious, hence the primary pollutants (principal component) at these sampling sites (Jassim et al. 2018).

\section{Cluster analysis}

Hierarchical Cluster Analysis (HCA) is a useful multivariate tool for finding patterns and groupings within a given data set; each one of them representing concentrations of the particulate matter $(\mathrm{Zn}$ and $\mathrm{Pb}$ ) (Núñez-Alonso et al. 2019). Cluster analysis involves splitting a given set of data into several group observations with unique characteristics in terms of common values or attributes of the group. Hence hierarchical cluster analysis aims to maximize between-group variance and further minimize within variance in the same group. A major advantage is that any number of variables can be used to group members of the given sample (Saksena et al. 2003).

Hierarchical cluster analysis will show how these particulate heavy metals and sampling sites relate to each other and thus plotted in a dendrogram using origin 2.0 Software as shown in Fig. 6. A two-cluster solution was selected to perform analysis for each particulate matter. The dendrogram shows that there are five primary clusters (cluster 1 , cluster 2 , cluster 3 , cluster 4 , and cluster 5) built into two other clusters when an imaginary straight line is drawn across from 0.2 scalings. The cluster also shows that these particulate metals relate with each other beyond their sampling sites. These can be seen for instance in Fig. 7 that sample points 1, 3, and 7 (cluster 1) is closely related to sampling points 5 and 21 on the same cluster. Similarly, on the far right-hand side (cluster 4), it shows that sampling points 2 and 30 are more closely related than 27 and 31 in cluster 5 . Also, from cluster 2, sampling points 11,13 , and 15 are commonly related to 10,14 , and 16 than any data in cluster 1 and cluster 3 and 5. Hence there are multiple levels of clustering showing similarity of measurement and relationship in terms of levels of concentration among the data sets regardless of the measured particulate matter. Thus cluster 2 is closer in similarity to any of cluster 1 and cluster 3 than 4 and 5 because the distance between them is almost twice.

However, it took half of the dendrogram to join cluster 1 and cluster 2 together which means that they are quite different but more closely related to each other in terms of the levels of concentration than cluster 3 which took $3 / 4$ of the dendrogram. Finally, the distance needed for clusters 4 and 5 to join clusters 1, 2, and 3 took the other half of the dendrogram which means that the concentration levels from clusters 4 and 5 are entirely dissimilar from other sampling points.

\section{Enrichment factor (EF)}

The Enrichment factor (EF) is applied in the statistical analysis of data to identify the anthropogenic source of metallic pollutants. It is useful in the determination of the degree of enrichment of a particular element compared to the relative abundance of that element in crustal material (Kothai et al. 2011). From our study, the crustal $\mathrm{EF}$ is calculated using Iron (Fe) as the reference material. The elemental compositions of soil in Enugu and Abakaliki are used from Chibuike et al. (2019) and (Okolo et al. 2013), whereas the aerosol levels are also calculated from Offor et al. (2016). The formula used for enrichment calculation is $\mathrm{EF}_{i}=(i / j)_{\text {air }} /(i / j)_{\text {crust }}$ where $\mathrm{EF}_{i}$ is the enrichment factor of $\mathrm{Zn}$ and $\mathrm{Pb}$ species of $I$, $J$. where $I_{\text {air }}$ is the content of the measured species in the examined environment, and $J_{\text {air }}$ is the content of the examined metal in the reference environment. $I_{\text {crust }}$ is the value of the reference element in the examined environment and $J_{\text {crust }}$ is the value of the reference element in the reference environment (Shaari et al. 2015). From our results, all the EF for $\mathrm{Pb}$ at all stations in Enugu was below 9 suggesting that the crustal source is dominant. While EF level at Abakaliki was between 10 and 11 meaning that the non-crustal source is the dominant source. For all calculated EF, Zn values were between 3 and 5 in both towns which indicate minor to moderate enrichment of crustal source.

\section{Pollution indices}

The overall suspended particulate matter pollution indices and their severity were determined using the Contamination Factor (CF) and Pollution Load Index (PLI). The CF and PLI were calculated using the straightforward mathematical expression by muller in 1969 and Tomlinson in 1980. Detailed explanations can be found in recent publications by Nagarajan et al. (2019) and Kowalska et al. (2018). The identification of contamination level of trace/heavy metal in the environmental matrix analysis is determined using Cf, while the PLI factors into consideration, the potential contribution of all elements to indicate the extent of pollution in a particular location. In this analysis, the soil metal concentrations and soil background concentrations were obtained using methods described by Basha et al. (2010) and Ercilla-Montserrat et al. (2018).

The results showed that CF for (Zn) at any of the Abakaliki sampling sites was $1=\mathrm{CF}<3$ which implies moderate contamination, nevertheless $\mathrm{CF}$ for $(\mathrm{Zn})$ at Enugu sampling sites revealed $\mathrm{CF}<1$ at any sampling site and refers to low contamination levels. The calculated PLI $(\mathrm{Pb})$ values for the entire Abakaliki and Enugu 
location were 1.318 and $1.603(>1)$, hence an indication of $\mathrm{Pb}$ pollution. On the other hand, PLI $(\mathrm{Zn})$ values for the entire Abakaliki was $>1$ (1.145) while PLI $(\mathrm{Zn})$ values for the entire Enugu (0.0381) were less $<1$ and indicates no pollution. The overall effect is that Abakaliki has $\mathrm{Zn}$ particulate matter enrichment, while the entire sampling location and site is at risk of $\mathrm{Pb}$ particulate matter pollution. The findings depict the relationship that exist between polluted soil and atmospheric suspended particulate matter in the study location.

\section{Conclusions}

The concentration levels of suspended $\mathrm{Zn}$ and $\mathrm{Pb}$ particulate matter were investigated at 10 sampling sites, during the August break period of the rainy season in Abakaliki and Enugu towns of Southeastern, Nigeria. Pb concentrations levels almost exhibited significant differences among the sites, owing to distance and source of emission while $\mathrm{Zn}$ levels showed no significant levels at all locations. The most dominant concentration levels were at AMN 1-4, ECM 1-4, and ECC 1-4 which represents Onu Nwafor/Okposhi Umughara quarry in Abakaliki and, Ogbete main market in Enugu and Coal camp in Enugu respectively. The results of PCA, HCA, and Pearson's correlation applied to ambient air quality monitoring study have proven to be useful towards the assessment of air quality not only showing primary pollutants but also the strong link that exists between $\mathrm{Zn}$ and $\mathrm{Pb}$ pollutants at Enugu and Abakaliki, which provided a deeper understanding into some of the mechanism involved. The enrichment factor showed that $\mathrm{Pb}$ had a crustal dominant source. The final results can be useful for local authorities in designing and planning particulate matter air pollution control measures for heavy metals during the August break. Hence biannual study is recommended in future work.

\section{Abbreviations}

ACM: Abakaliki commercial area; AIN: Abakaliki industrial area; AMN: Abakaliki mining area; ARR: Abakaliki rural area; ARS: Abakaliki residential area; CF: Contamination factor; ECC: Enugu coal camp; ECM: Enugu commercial area; EF: Enrichment factor; EIN: Emene industrial layout; ERR: Enugu rural site; ERS: Enugu residential area; FMEnv: Federal ministry of environment; FRN: Federal Republic of Nigeria; HCA: Hierarchical cluster analysis; NAAQS: National ambient air quality standard; NESREA: National environmental standards and regulation agency; PCA: Principal component analysis; PLI: Pollution load index; SPM: Suspended particulate matter; US EPA: United states environmental protection agency.
\end{abstract}

\section{Supplementary Information}

The online version contains supplementary material available at https://doi. org/10.1186/s42269-021-00618-7.

Additional file 1. Spatial distribution of meteorological parameters.

\section{Acknowledgements}

The authors wish to acknowledge the support of the Projects Development Institute (PRODA), Enugu, Nigeria, and the Federal University of Technology, Owerri, Imo State Nigeria, towards the completion of this work.

\section{Authors' contributions}

$\mathrm{BCl}, \mathrm{AlO}$, and ENE were involved in the study design and fieldwork. ENE and $\mathrm{BCl}$ carried out the laboratory analysis and interpreted the data from suspended particulate matter measurements. $\mathrm{AUN}, \mathrm{FCl}$, and ECD provided statistical data software, analysis, and interpretation. AUN ad AIO were the major contributors in writing the manuscript. All authors read and approved the final manuscript.

Funding

Not applicable.

\section{Availability of data and materials}

All data generated or analyzed during this study are included in this published article and its supplementary information files.

\section{Declarations}

Ethics approval and consent to participate Not applicable.

Consent for publication

Not applicable.

\section{Competing interests}

The authors declare that no competing interests exist for this work.

\section{Author details}

${ }^{1}$ Materials and Energy Technology Department, Projects Development Institute (PRODA), P.M.B. 01609, Enugu, Nigeria. ${ }^{2}$ Department of Geology, Federal University of Technology Owerri, P.M.B. 1526, Owerri, Imo, Nigeria. ${ }^{3}$ Department of Chemistry, Federal University of Technology Owerri, P.M.B. 1526,

Owerri, Imo, Nigeria. ${ }^{4}$ Department of Chemistry, Imo State University Owerri, P.M.B. 2000, Owerri, Nigeria.

Received: 4 May 2021 Accepted: 9 September 2021

Published online: 23 September 2021

\section{References}

Abdul-Wahab SA (2006) Indoor and outdoor relationships of atmospheric particulates in Oman. Indoor Built Environ 15:247-255. https://doi.org/10. 1177/1420326×06066322

Adam ME (2013) Suspended particulates concentration (PM10) under unstable atmospheric conditions over a subtropical urban area (Qena, Egypt). Adv Meteorol. https://doi.org/10.1155/2013/457181

Al-Anzi B, Abusam A, Khan A (2016) Evaluation of temporal variations in the ambient air quality at Jahra using multivariate techniques. Environ Technol Innov 5:225-232. https://doi.org/10.1016/j.eti.2016.04.003

Ali H, Khan E, llahi I (2019) Environmental chemistry and ecotoxicology of hazardous heavy metals: environmental persistence, toxicity, and bioaccumulation. J Chem. https://doi.org/10.1155/2019/6730305

Aloha OG, Obasi NA, Chukwu KE, Agu AN (2016) Effects of lead-zinc mining activities on water and soil quality in Ameka mining area of Ezza South, Ebonyi State, Nigeria. Int Res J Nat Appl Sci 3:194-231

Aloha GA, Aloh HE, Obasi AN, Chukwu K (2017) Evidence of heavy metal contamination of agricultural soil in Ameri, Abakaliki lead-zinc mining area, Ebonyi state southeast Nigeria: an indication for Phytoremediation. Nutr Food Technol Open Access 3:1-5. https://doi.org/10.16966/24706086.145

Awan MA, Ahmed SH (2011) Determination of total suspended particulate matter and heavy metals in ambient air of four cities of Pakistan. Iran J Energy Environ 2:128-132

Awokola Bl, Okello G, Mortimer KJ et al (2020) Measuring air quality for advocacy in Africa (MA3): feasibility and practicality of longitudinal ambient 
PM 2.5 measurement using low-cost sensors. Int J Environ Res Public Heal 17:1-17. https://doi.org/10.20944/preprints202009.0613.v1

Basha S, Gaur P, Thorat R (2007) Heavy metal content of suspended particulate matter at world's largest ship-breaking yard, Alang-Sosiya, India. Water Air Soil Pollut 178:373-384. https://doi.org/10.1007/s11270-006-9205-z

Basha S, Jhala J, Thorat R et al (2010) Assessment of heavy metal content in suspended particulate matter of coastal industrial town, Mithapur, Gujarat, India. Atmos Res 97:256-265. https://doi.org/10.1016/j.atmosres. 2010.04.012

Benibo AG, Shaato R, Wuana RA, Itodo AU (2020) Assessment of ambient air quality around Ihetutu minefield, Ishiagu, Nigeria. J Chem Soc Niger 45:1203-1214. https://doi.org/10.46602/jcsn.v45i6.554

Bermudez-Edo M, Barnaghi P, Moessner K (2018) Analyzing real-world data streams with Spatio-temporal correlations: entropy vs. pearson correlation. Autom Constr 88:87-100. https://doi.org/10.1016/j.autcon.2017.12. 036

Briffa J, Sinagra E, Blundell R (2020) Heavy metal pollution in the environment and their toxicological effects on humans. Heliyon 6:e04691. https://doi. org/10.1016/j.heliyon.2020.e0469

Chen J, Dahlin M, Luuppala L et al (2021) Air pollution and climate change: sustainability, restoration, and ethical implications. In: Goodsite ME, Johnson MS, Hertel O (eds) Air pollution sources, statistics and health effects. Springer, New York, pp 279-325

Chibuike IE, Chukwuemeka OD, Chukwudi EC (2019) Heavy metal geochemistry of soils in selected industrial and farmlands of Enugu state: a preliminary investigation. Sci Res J VIl:15-26. https://doi.org/10.31364/ scirj/v7.i6.2019.p0619659

Cimboláková I, Uher I, Veszelits L et al (2020) Heavy Metals and the environment. In: Ivan $\mathrm{U}$ (ed) environmental factors affecting human health. IntechOpen, London, pp 1-31

Douglas DW (2009) Health effects of particulate air pollution. Ann Epidemiol 19:257-263. https://doi.org/10.1016/j.annepidem.2009.01.018

El-Shamy A, El Boraey H, El-Awdan H (2017a) Chemical treatment of petroleum wastewater and its effect on the corrosion behavior of steel pipelines in sewage networks. J Chem Eng Process Technol 8:1-9. https://doi.org/10. 4172/2157-7048.1000324

El-Shamy A, Farag H, Saad W (2017b) Comparative Study of removal of heavy metals from industrial wastewater using clay and activated carbon in batch and continuous flow systems. Egypt J Chem 60:1165-1175. https:// doi.org/10.21608/ejchem.2017.1606.1128

El-Shamy A, Abdelfattah I, Elshafey O, Shehata M (2018) Potential removal of organic loads from petroleum wastewater and its effect on the corrosion behavior of municipal networks. J Environ Manag 219:325-331. https:// doi.org/10.1016/j.jenvman.2018.04.074

Ercilla-Montserrat M, Muñoz P, Montero Jl et al (2018) A study on air quality and heavy metals content of urban food produced in a Mediterranean city (Barcelona). J Clean Prod. https://doi.org/10.1016/j.jclepro.2018.05. 183

Fagorite V, Anifowose A, Chiokwe N (2021) Air pollution; causes, effects, and remediation in Nigeria. Int J Adv Acad Res 7:13-30. https://doi.org/10. 46654/ij.24889849.e7114

Frank J, Poulakos A, Tornero-Velez R, Xue J (2019) Systematic review and metaanalyses of lead $(\mathrm{Pb})$ concentrations in environmental media (soil, dust, water, food, and air) reported in the United States from 1996 to 2016. Sc Total Environ 694:1-18. https://doi.org/10.1016/j.scitotenv.2019.07.295

FRN (2009) Report on the census 2006 final results. In: Fed. Repub. Niger. Off. Gaz. https://gazettes.africa/archive/ng/2009/ng-government-gazettedated-2009-02-02-no-2.pdf. Accessed 29 Mar 2021

Gharaibeh A, El-Rjoob AW, Harb M (2010) Determination of selected heavy metals in air samples from the northern part of Jordan. Environ Monit Assess 160:425-429. https://doi.org/10.1007/s10661-008-0706-7

Ghosh S, Bakshi M, Mahanty S et al (2021) Spatiotemporal distribution of potentially toxic elements in the lower Gangetic delta and their implications for non-carcinogenic health risk management. Geosci Lett 8:1-14. https://doi.org/10.1186/s40562-021-00189-5

Gray D, Wallace L, Brinkman M et al (2015) Respiratory and cardiovascular effects of metals in ambient particulate matter: a critical review. Rev Environ Contam Toxicol 234:135-203. https://doi.org/10.1007/ 978-3-319-10638-0_3

Hůnová I (2020) Ambient air quality in the Czech Republic: past and present. Atmosphere 11(2):1-26. https://doi.org/10.3390/atmos11020214
Ibe F, Opara A, Njoku P, Alinnor J (2017) Ambient air quality assessment of orlu, southeastern, Nigeria. J Appl Sci 17:441-457. https://doi.org/10.3923/jas. 2017.441 .457

Ichu C, Umeh J, Opara A, Ibe F (2021) Ecological risk assessment and pollution models of trace metal concentrations in road dust in parts of Enugu, southeastern Nigeria. J Chem Heal Risk 11:1-17. https://doi.org/10.22034/ jchr.2021.1896397.1116

Ikamaise VC, Akpan IO, Essiet AA, Uwah IE (2013) Concentrations and source apportionment of total suspended particulate matter in Calabar Air Basin. Int J Dev Sustain 2:1203-1213

Jassim MS, Coskuner G, Marzooq H et al (2018) Spatial distribution and source apportionment of air pollution in bahrain using multivariate analysis methods. Environ Asia 11:9-22. https://doi.org/10.14456/ea.2018.19

Kothai P, Saradhi I, Pandit G et al (2011) Chemical characterization and source identification of particulate matter at an urban site of Navi Mumbai, India. Aerosol Air Qual Res 11:560-569. https://doi.org/10.4209/aaqr.2011.02. 0017

Kowalska J, Mazurek R, Gąsiorek M, Zaleski T (2018) Pollution indices as useful tools for the comprehensive evaluation of the degree of soil contamination-a review. Environ Geochem Health 40:2395-2420. https://doi.org/ 10.1007/s10653-018-0106-z

Maduna K, Tomasic V (2017) Air pollution engineering. Phys Sci Rev 2:1-29. https://doi.org/10.1515/psr-2016-0122

Migahed F, Abdelrazak A, Fawzy G (2017) Batch and continuous removal of heavy metals from industrial effluents using microbial consortia. Int J Environ Sci Technol 14:1169-1180. https://doi.org/10.1007/ s13762-016-1229-3

Mukherjee A, Agrawal M (2017) World air particulate matter: sources, distribution and health effects. Environ Chem Lett 15:283-309. https://doi.org/10 1007/s10311-017-0611-9

Nagarajan R, Anandkumar A, Hussain S et al (2019) Geochemical characterization of beach sediments of Miri, NW Borneo, SE Asia: implications on provenance, weathering intensity, and assessment of coastal environmental status. Coast Zo Manag. https://doi.org/10.1016/b978-0-12814350-6.00012-4

Ngele SO, Onwu FK (2015) Measurements of ambient air fine and coarse particulate matter in ten. South-East Nigerian cities. Res J Chem Sci 5:71-77

Núñez-Alonso D, Pérez-Arribas LV, Manzoor S, Cáceres JO (2019) Statistical tools for air pollution assessment: Multivariate and spatial analysis studies in the Madrid region. J Anal Methods Chem 2019:1-9. https://doi.org/10. 1155/2019/9753927

Obioh I, Olise F, Owoade O, Olaniyi H (2005) Chemical characterisation of suspended particulates along air corridors of motorways in two Nigerian cities. J Appl Sci 5:347-350. https://doi.org/10.3923/jas.2005.347.350

Offor IF, Adie GU, Ana GR (2016) Review of particulate matter and elemental composition of aerosols at selected locations in Nigeria from 1985-2015. J Heal Pollut 6:1-18. https://doi.org/10.5696/2156-9614-6-10.1

Ogbonna PC, Nzegbule EC, Okorie PE (2014) Environmental impact assessment of coal mining at Enugu, Nigeria. Impact Assess Proj Apprais 33:73-79. https://doi.org/10.1080/14615517.2014.941711

Ojekunle OZ, Jinadu OO, Afolabi TA, Taiwo AM (2018) Environmental pollution and related hazards at Agbara industrial area, Ogun state. Sci Rep 8:1-8. https://doi.org/10.1038/s41598-018-24810-4

Okolo CC, Ezeaku PI, Nwite JN et al (2013) Environmental and agronomic implication of the levels of heavy metals contamination of the soils along Enugu-Abakaliki major highway in southeastern Nigeria. Elixir Agric 61:17040-17046

Rodriguez MG, Heredia Rivera B, Rodriguez Heredia M, Rodriguez Heredia B, Gonzalez Segovia R (2019) A study of dust airborne particles collected by vehicular traffic from the atmosphere of southern Megalopolis Mexico City. Environ Syst Res 8:1-17. https://doi.org/10.1186/s40068-019-0143-3

Sahu C, Basti S (2021) Metal pollution in the environment: a review. Int J Environ Sci Technol 18:211-224. https://doi.org/10.1007/s13762-020-02779-w

Saksena S, Joshi V, Patil RS (2003) Cluster analysis of Delhi's ambient air quality data. J Environ Monit 5:491-499. https://doi.org/10.1039/b210172f

Seibokuro B, Angaye TC, Konmeze O (2018) Assessment of the fate and intensity of particulate matter associated with playgrounds in trafficcongested areas of Yenagoa metropolis, Nigeria. MOJ Toxicol 4:432-4381. https://doi.org/10.15406/mojt.2018.04.00141

Shaari H, Mohamad Azmi SN, Sultan K et al (2015) Spatial distribution of selected heavy metals in surface sediments of the EEZ of the East Coast 
of peninsular Malaysia. Int J Oceanogr 618074:1-10. https://doi.org/10. $1155 / 2015 / 618074$

Shah S (2021) Heavy metals in the marine environment-an overview. In: Heavy metals in scleractinian corals. Springer briefs in earth sciences. Springe, pp 1-26

Shehata M, El-Shafey S, Ammar N, El-Shamy A (2019) Reduction of Cu+2 and $\mathrm{Ni}+2$ ions from wastewater using mesoporous adsorbent: effect of treated wastewater on corrosion behavior of steel pipelines. Egypt J Chem 62:1587-1602. https://doi.org/10.21608/ejchem.2019.7967.1627

Simeonov V, Tsakovski S, Lavric T et al (2004) Multivariate statistical assessment of air quality: a case study. Microchim Acta 148:293-298. https://doi.org/ 10.1007/s00604-004-0279-2

Sintorini MM (2018) The impact of total suspended particulate concentration on workers' health in the ceramic industry. IOP Conf Ser Earth Environ Sci 106:1-7. https://doi.org/10.1088/1755-1315/106/1/012034

Ukaogo P, Ewuzie U, Onwuka C (2020) Environmental pollution: causes, effects, and the remedies. Microorg Sustain Environ Heal. https://doi.org/10. 1016/b978-0-12-819001-2.00021-8
U.S EPA (1990) NAAQS table. In: U.S Environ. Prot. Agency. (1990). NAAQS table. US EPA. https://www.epa.gov/criteria-air-pollutants/naaqs-table. Accessed 19 Feb 2021

U.S EPA (1999) Air quality criteria for particulate matter. In: Integr. Sampl. Suspended Part. Matter Ambient Air. https://www.epa.gov/sites/default/ files/2019-11/documents/overvw2.pdf. Accessed 11 Feb 2021

Yu F, Qiu F, Meza J (2016) Design and statistical analysis of mass-spectrometrybased quantitative proteomics data. In: Proteomic profiling and analytical chemistry, 2nd edn. pp 211-237

\section{Publisher's Note}

Springer Nature remains neutral with regard to jurisdictional claims in published maps and institutional affiliations.

\section{Submit your manuscript to a SpringerOpen ${ }^{\odot}$ journal and benefit from:}

- Convenient online submission

- Rigorous peer review

- Open access: articles freely available online

- High visibility within the field

- Retaining the copyright to your article

Submit your next manuscript at $\boldsymbol{\nabla}$ springeropen.com 